\title{
Foraging behavior and pollinating effectiveness of $O$ smia cornuta (Hymenoptera: Megachilidae) and Apis mellifera (Hymenoptera: Apidae) on "Comice" pear
}

\author{
Víctor H. MONZÓN ${ }^{\mathrm{a}, \mathrm{b}}$, Jordi BosCH ${ }^{\mathrm{c}, \mathrm{b} *}$, Javier ReTANA ${ }^{\mathrm{b}}$ \\ a Laboratorio de Inmunología y Genética Molecular, Instituto de Biología, \\ Universidad Católica de Valparaíso, Chile \\ b Unitat d'Ecologia, Facultat de Ciències, Universitat Autònoma de Barcelona, 08193 Bellaterra, Spain \\ ${ }^{c}$ Biology Department, Utah State University, Logan, UT 84322-5310, USA
}

(Received 3 April 2003; revised 20 January 2004; accepted 5 February 2004)

\begin{abstract}
We studied the pollinating effectiveness of Osmia cornuta and Apis mellifera on 'Comice' pear. Osmia cornuta visited more flowers per minute (13.8) than A. mellifera (7.1-9.8). Both species visited similar numbers of flowers per tree (6.7-7.9), and switched rows with similar frequency (4.0-7.9\%). Rate of stigma contact was $98.7 \%$ for O. cornuta, $51.8 \%$ for A. mellifera pollen-nectar foragers, and $19.0 \%$ for A. mellifera nectar foragers. Fruit-set in flowers visited once was $28.9,29.3$, and $12.9 \%$, respectively. Seedset was similar (7-8 seeds per fruit) in all three types of flowers. Osmia cornuta females provisioned their nests with $94.4 \%$ pear pollen. Stepwise multiple regression showed that fruitlet-set across the orchard was mostly related to tree size (trees with fewer flowers set more fruit per flower) $(\beta=-0.64 ; P<0.001$ ), whereas seed-set at harvest was best explained by $O$. cornuta $(\beta=0.47 ; P<0.005)$ and $A$. mellifera $(\beta=0.35 ; P<0.05)$ spatial distribution.
\end{abstract}

Osmia cornuta / Apis mellifera / pollinating effectiveness / pear pollination

\section{INTRODUCTION}

Most commercial cultivars of pear, Pyrus communis L., are self-incompatible or produce more and/or better fruit when cross-pollinated (Nyéki, 1996). For this reason, rows of pollinizer cultivars are normally planted among rows of the main cultivar in pear orchards, and 2.5-4 honey bee, Apis mellifera L., colonies per ha are introduced to ensure adequate pollen transfer (McGregor, 1976; Free, 1993; Benedek, 1996). However, insufficient pollination is a common cause of poor yields in pear (Sotes Ruiz, 1977; Soltész, 1996a). The sugar content of pear nectar is low (often $<10 \%$ ) compared to that of other fruit tree species with overlap- ping flowering periods (apple, Malus domestica Borkh, peach, Prunus persica L., cherry, Prunus avium L.) (McGregor, 1976; Free, 1993; Soltész, 1996b). Apis mellifera workers visiting pear blossoms often switch to other fruit tree species or to other, more rewarding plants including Sinapis alba L., Stellaria spp., Taraxacum officinale Webber and Crataegus monogyna Jacq. when these start to bloom (review in Free, 1993).

"Comice" pear is highly self-incompatible (Callan and Lombard, 1978), and typically has poor productivity, even when planted in orchards with cross-compatible cultivars (Joumien, 1968; Bini and Bellini, 1971; Callan and Lombard, 1978). The poor productivity of "Comice" pear

\footnotetext{
* Corresponding author: Jordi.Bosch@uab.es
} 
is at least partially explained by its brief effective pollination period, which lasts only 1-2 days at 9-10 ${ }^{\circ} \mathrm{C}$ (Lombard et al., 1971; Crisosto et al., 1988). In other words, although stigmas remain receptive for longer periods, pollination needs to be accomplished in the first 1-2 days after anthesis for fertilization to occur before ovule degeneration (Nyéki and Bubán, 1996). Parthenocarpy in "Comice" is not as common as in other pear cultivars (Stephen, 1958; Joumien, 1968).

Osmia cornuta (Latreille) is an early-flying mason bee that has been studied as an orchard pollinator (Asensio, 1984; Torchio and Asensio, 1985; Krunic et al., 1991; Bosch, 1994a, b). Osmia cornuta is strongly attracted to fruit tree flowers, and nests produced in orchards contain 78-99\% pollen of the target crop (Márquez et al., 1994; Vicens and Bosch, 2000a; Maccagnani et al., 2003). In a recent study in a pear orchard pollinated almost exclusively with $O$. cornuta, seed-set was comparable to seed-set in trees caged with abundant pollinators, and, in some cultivars/years, fruit-set was found to decrease at increasing distances from the $O$. cornuta nesting shelters (Maccagnani et al., 2003). The pollinating effectiveness of $O$. cornuta is near $100 \%$ on almond and apple (Bosch and Blas, 1994; Vicens and Bosch, 2000a). To our knowledge, the foraging behavior and individual pollinating effectiveness of $O$. cornuta on pears have not been previously reported. The aim of our study was to determine whether $O$. cornuta will establish in pear orchards and provision nests with pollen of this species, and to study its foraging behavior and pollinating effectiveness on pear in comparison to A. mellifera. We were also interested in determining whether it is possible to sustain $O$. cornuta populations in pear orchards.

\section{MATERIALS AND METHODS}

\subsection{Study orchard and flowering phenology}

Field work was conducted in April 1996 at Can Oller, a 100-ha pear plantation in Cassà de la Selva (Girona, NE Spain; $46^{\circ} 37^{\prime} \mathrm{N}, 4^{\circ}$ 90' E). We worked at a 3.8-ha orchard with 28 rows of 300 trees each. The main cultivar ("Comice") was planted in 3 blocks of 8 rows each. "Comice" blocks were separated from each other by 2 rows of pollenizers ("Duc de Bordeaux" and "Conference"; Fig. 1). Distance

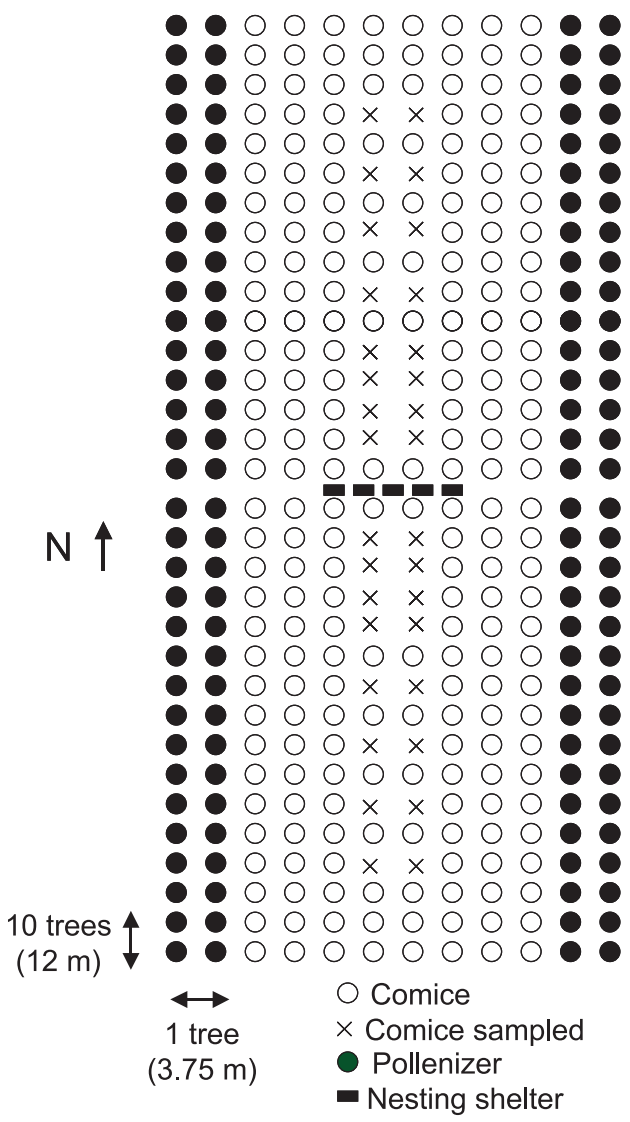

Figure 1. "Comice" block showing pollenizer distribution, trees sampled, and Osmia cornuta nesting shelter distribution. Two additional 8-row "Comice" blocks were located East and West of the block shown. The closest Apis mellifera colonies were located $220 \mathrm{~m} \mathrm{SE}$ of the O. cornuta nesting shelters.

between rows was $3.75 \mathrm{~m}$, and distance between adjacent trees within a row was $1.2 \mathrm{~m}$, so that their limbs sometimes overlapped. Trees were eight years old, approximately $2.5 \mathrm{~m}$ tall and pruned in a central leader system. Adjacent orchards were planted with the cultivar "Passa Crassana". The flowering phenology of the cultivars "Comice", "Duc de Bordeaux", "Conference" and "Passa Crassana" was estimated on 4 tagged limbs (oriented to N, S, E and W, respectively) on each of 10 trees of each cultivar. Every morning throughout the flowering period, we counted the number of new open flowers on each tagged limb. Honey bee colonies were introduced across the Can Oller farm at a rate of 5 colonies (with 4 frames of brood) per ha. A group of 8 colonies was located $20 \mathrm{~m}$ away from the southeast corner of the study orchard. 


\subsection{Management of Osmia cornuta populations}

Five $O$. cornuta nesting shelters were set up in five adjacent rows in the middle of the "Comice" orchard (Fig. 1). Each shelter consisted of a wooden box with the front side open held at $1.5 \mathrm{~m}$ above the ground by 4 metal fence posts. Each shelter contained 20 solid wood blocks with 25 drilled holes per block (Bosch, 1995). A paraffin-coated paper straw (15 cm long, $8 \mathrm{~mm}$ inside diameter) was inserted in each hole. On 3 April, an O. cornuta population consisting of 707 females and 1996 males was released in the orchard. Most bees (656 females and 1708 males) had been reared from trap-nests (wood blocks identical to those described above) placed in several locations near Girona in 1995. The remaining bees (51 females and 288 males) were the progeny of a population managed for almond pollination in Murcia (SE Spain). Both groups of bees had been reared at $25-30{ }^{\circ} \mathrm{C}$ during spring-summer of the previous year. By mid September, when bees had reached the adult stage, paper straws were dissected. Cocoons were then removed and sexed, female cocoons being larger and typically located in the innermost cells within a nest (Bosch, 1994b). Cocoons were then wintered at $3{ }^{\circ} \mathrm{C}$ until the following spring, when female cocoons were individually inserted in paper straws, which were evenly distributed among nesting wood blocks in the five nesting shelters $(\sim 140$ females per shelter). Male cocoons were placed in open cardboard boxes set in the nesting shelters. Cocoons from the Murcia population were kept separate from those of the Girona population. Every other day after release, straws with inserted female cocoons were inspected to determine female emergence. On 11 and 16 April, all nesting cavities were inspected at night with a flashlight to count the number of females established in the nesting wood blocks.

Osmia cornuta nesting materials were removed from the nesting shelters in early May, after petal fall. Straws in which female cocoons had been inserted for release were examined to determine female emergence percentages. Paper straws containing $O$. cornuta progeny were incubated at $25^{\circ} \mathrm{C}$ throughout the summer. At the end of August, when progeny had reached the adult stage, each nest was dissected and its contents analyzed. Cells were counted and sexed as described above for the parental population. Developmental mortality and parasitism were also recorded. Fecal samples from 110 randomly-chosen cells were mounted on fuchsinstained gelatin microscope slides (Beattie, 1971), and 300 pollen grains per cell were identified to genus or tribe level under the microscope $(100 \mathrm{X})$ using a reference pollen collection. Because pear was the only fruit tree in bloom in Can Oller throughout the study and most $O$. cornuta females forage within $200 \mathrm{~m}$ from their nesting site (Vicens and Bosch, 2000a, b), all pollen identified as Rosaceous fruit tree was assumed to be pear.

\subsection{Pollinator counts}

Pollinator counts were made on 32 "Comice" trees ( 8 trees of each of 4 rows) located at increasing distances from the $O$. cornuta nesting shelters (Fig. 1). All 4 rows sampled were 4 rows away from a pollenizer row. The first four trees sampled in each of the four rows were $12 \mathrm{~m}$ apart from each other (10 tree-intervals). The last four trees in each row were $24 \mathrm{~m}$ (20 trees) apart from each other. Counts were conducted on 10 days throughout the flowering period of "Comice". Four counts were completed daily at $0900-1000,1200-1300,1500-1600$, and 1800-1900 h local time. During each count, each tree was observed for $1 \mathrm{~min}$, and all insects seen visiting flowers were recorded. To avoid altering visitation frequencies, recorded insects were not captured.

\subsection{Foraging behavior and pollinating effectiveness}

Data on foraging behavior were obtained at "Comice" peak bloom and on days with weather favorable to both $O$. cornuta and A. mellifera activity. Female $O$. cornuta and worker $A$. mellifer $a$ were followed from their first flower visit to a tree until we lost sight of them. Data were gathered on: (1) resources collected (nectar and/or pollen); (2) stigma contact (pear blossoms have 5 stigmas and it is difficult to ascertain how many are contacted, so we scored visits as either contacting some stigmas or none); (3) visitation rates (flowers visited per minute); (4) number of flowers visited per tree; and (5) relative position of consecutively visited trees (adjacent trees in the same row, other trees in the same row, trees in other rows).

Pollinating effectiveness was measured over four consecutive days (20-23 April) by letting non-visited flowers of trees located in the same rows as those used to count pollinators, be visited once by either $O$. cornuta or A. mellifera. "Comice" limbs with flower buds were covered with fine mesh nylon bags (0.5 mm-openings) to prevent insect visitation and inspected daily. When open flowers were available (first day of anthesis), they were unbagged and watched continuously until either a female $O$. cornuta or a worker A. mellifer $a$ visited a flower. Visited flowers (only one visit per flower was allowed) were labeled and rebagged. Data on bee species, resources collected (pollen and/or nectar), and stigma contact were recorded for each flower visit. On 20 May, after petal fall and before the June drop, developing fruits (fruitlets) were collected and their number of seeds counted. 


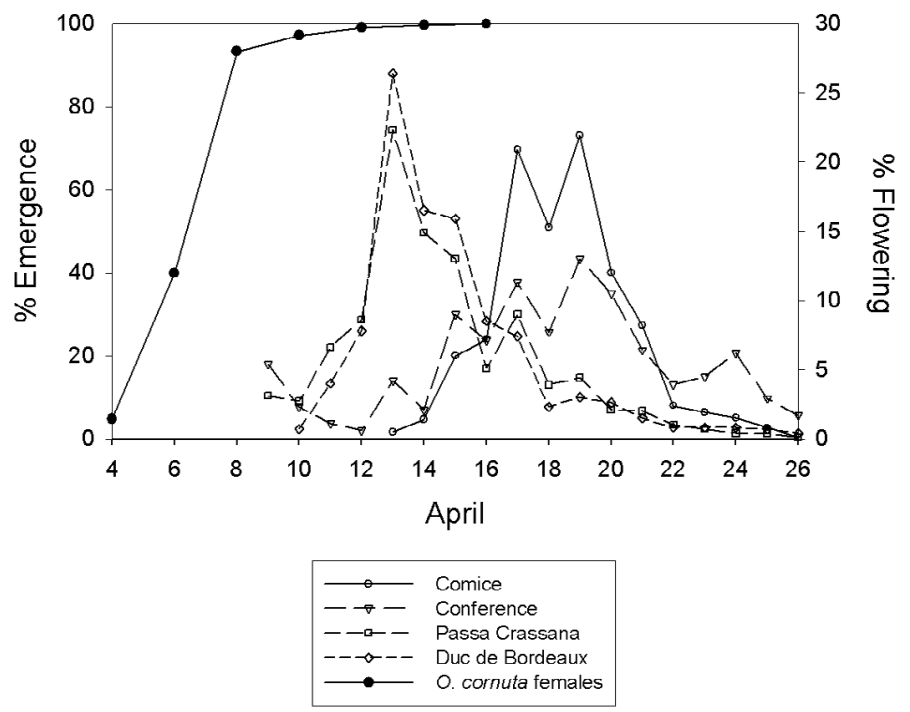

Figure 2. Female Osmia cornuta emergence and flowering phenology of pear cultivars in Can Oller in 1996.

On 20 April, shortly before bloom initiation, we counted all inflorescence buds in the same 32 "Comice" trees used for the pollinator counts. We then multiplied the number of inflorescence buds by 5 to obtain an estimate of number of flowers per tree. Fruitlets produced in these trees were counted on 20 May, and then again on 15 September, at harvest. At that time, a sample of 25 fruits per tree was used to count seeds per fruit. Thus, we obtained a measure of fruitlet-set (developing fruits retained on the tree before the June drop/flowers produced), and seedset (seeds/fruit retained on the tree at harvest) across the orchard.

\subsection{Data analysis}

We used $G$-tests to analyze differences between pollinator species in stigma contact rate and frequency of flights between rows. Differences in visitation rates, flowers visited per tree and seed-set in single-visit flowers were analyzed with one-way ANOVA. Results obtained over the four days on which pollinating single-visit measurements were conducted were pooled together because there were no significant differences across dates in fruit-set, irrespective of whether all visits were considered $(G=4.631 ; \mathrm{df}=3 ; P>0.2)$ or only visits with stigma contact were considered $(G=3.801 ; \mathrm{df}=3 ; P>0.2)$. Seed number variances across pollinator type were homogeneous (Levene test: $F=0.249$; df $=2.52$; $P>0.7)$. To evaluate the effect of insect visitation on fruitlet-set and seed-set in the 32 trees sampled, we used Stepwise Multiple Regression. The independent variables were number of flowers per tree and frequency of A. mellifera, $O$. cornuta and other flower-visiting insects, respectively. Number of flowers per tree was included because preliminary exploration of the data showed a significant negative correlation between this variable and fruitlet-set. Multiple regression provides an estimate of the relative magnitudes of the contributions of the independent variables to the observed variation in the dependent variable (Sokal and Rohlf, 1995). Tolerance of all four independent variables was $>0.58$ in all analyses, indicating absence of excessive collinearity (Quinn and Keough, 2002).

\section{RESULTS}

\subsection{Osmia cornuta emergence}

Female $O$. cornuta emergence started on 4 April, one day after release, and by 8 April female emergence was $>90 \%$ (Fig. 2). The first mating pairs were observed on 5 April, and four days later females were seen inspecting nesting cavities. On 11 April, in synchrony with the beginning of pear bloom in the orchard, some females were seen provisioning nesting cavities with pollen loads. The first completed (plugged) O. cornuta nests were observed on 
Table I. Visit effectiveness (visits in which at least one stigma was contacted), visitation rates, and number of flowers visited consecutively per tree in Osmia cornuta females and Apis mellifera workers on "Comice" pear.

\begin{tabular}{|c|c|c|c|c|c|c|}
\hline & \multicolumn{3}{|c|}{ Effective visits } & $\begin{array}{l}\text { Visitation rates } \\
\text { (flowers/minute) }\end{array}$ & \multicolumn{2}{|c|}{ Visits/tree } \\
\hline & $n$ & $\%$ & $n$ & $\bar{x} \pm S E$ & $n$ & $\overline{\mathrm{x}} \pm \mathrm{SE}$ \\
\hline & \multicolumn{6}{|c|}{ Osmia cornuta } \\
\hline & 1047 & 98.7 & 68 & $13.8 \pm 0.68$ & 76 & $6.7 \pm 0.5$ \\
\hline & \multicolumn{6}{|c|}{ Apis mellifera } \\
\hline Nectar foragers & 142 & 19.0 & 11 & $7.1 \pm 0.02$ & 16 & $7.1 \pm 1.0$ \\
\hline Pollen-nectar foragers & 336 & 51.8 & 26 & $9.8 \pm 0.05$ & 31 & $7.9 \pm 1.2$ \\
\hline
\end{tabular}

14 April. Pollen from pollenizer cultivars "Conference", "Duc de Bordeaux" and "Passa Crasana" was available throughout the 13-day flowering period of "Comice" (Fig. 1).

\subsection{Pollinator counts}

A total of 950 insects were recorded visiting "Comice" flowers. Apis mellifera was, by far, the most abundant species (55.4\% of the insects recorded). Osmia cornuta and wild bees amounted to $7.9 \%$ and $2.4 \%$ of the visits recorded, respectively. Most (88\%) O. cornuta recorded were female. Among the Diptera, the Syrphidae were particularly abundant (28.6\%). Other Diptera and other insects (mainly aculeate wasps and Lepidoptera) amounted to $5.3 \%$ and $0.4 \%$ of the visits recorded, respectively. Overall pollinator density was 0.74 insects per tree per minute.

\subsection{Foraging behavior and pollinating effectiveness}

Of the 110 O. cornuta fecal samples examined, $75.5 \%$ contained exclusively pear pollen, and $23.6 \%$ contained more than $80 \%$ pear pollen. Overall, $94.4 \%$ of the pollen grains identified were pear. Other pollens found were Erica, Quercus, Brassica, and Asteraceae (Sonchustype). Nesting $O$. cornuta females collect pollen and nectar simultaneously on pear flowers. They nearly always land on the reproductive organs of the flower and insert their proboscis to probe for nectar while they scrape the anthers with their hind legs to collect pollen on their ventral scopa. Contact of the bee and the stigmas was observed on $99 \%$ of the visits (Tab. I).
On most visits, all or most stigmas were contacted. Osmia cornuta males and pre-nesting females only collect nectar for their own consumption. However, males and pre-nesting females were also observed to contact the stigmas of pear flowers on most visits. Of the $A$. mellifera recorded, $40.7 \%$ collected only nectar. These individuals typically landed on the petals of the flower and very often probed the nectaries without contacting the stigmas (Tab. I). Other A. mellifera (59.3\%) collected both nectar and pollen. These individuals (henceforth, pollen foragers) also tended to land on the petals of the flower, but they made stigma contact on $52 \%$ of their visits, as they scraped the anthers to collect pollen (Tab. I). Differences in visit effectiveness between the three pollinator types were statistically significant $(G=734.5 ; \mathrm{df}=2 ; P<0.0001)$. Flower visitation rates also differed between pollinator types $(F=10.13$; df $=2,104 ; P<0.0001$; Tab. I). Instead, all three pollinator types visited similar numbers of flowers per tree $(F=0.47$; df $=$ 2,$120 ; P=0.62$; Tab. I). Both $O$. cornuta and A. mellifera tended to fly from one tree to an adjacent tree in the same row, and differences between pollinators in inter-row flight frequency were not significant $(G=0.50 ; \mathrm{df}=1$; $P=0.48$; Tab. II).

Fruitlet-set of single-visited flowers was more than twice as high for flowers visited by $A$. mellifera pollen-foragers or $O$. cornuta as for flowers visited by A. mellifera nectar-foragers $(G=7.62 ; \mathrm{df}=2 ; P<0.03$; Tab. III). The number of seeds per fruit did not differ significantly between flowers visited by the three pollinator types $(F=1.13$; df $=2,52 ; P=0.33$; 
Table II. Flights between pear trees by Osmia cornuta females and Apis mellifera workers (both nectar and pollen-nectar foragers).

\begin{tabular}{|c|c|c|c|c|c|c|c|}
\hline \multirow[t]{2}{*}{ Species } & \multirow[t]{2}{*}{$n$} & \multicolumn{2}{|c|}{$\begin{array}{l}\text { Adjacent trees } \\
\text { in same row }\end{array}$} & \multicolumn{2}{|c|}{$\begin{array}{l}\text { Other trees } \\
\text { in same row }\end{array}$} & \multicolumn{2}{|c|}{$\begin{array}{l}\text { Trees in } \\
\text { other rows }\end{array}$} \\
\hline & & $\mathrm{n}$ & $\%$ & $\mathrm{n}$ & $\%$ & $\mathrm{n}$ & $\%$ \\
\hline O. cornuta & 89 & 78 & 87.6 & 4 & 4.5 & 7 & 7.9 \\
\hline A. mellifera & 25 & 22 & 91.7 & 2 & 8.0 & 1 & 4.0 \\
\hline
\end{tabular}

Table III. Fruit- and seed-set in "Comice" flowers receiving a single visit by Osmia cornuta females or Apis mellifera workers.

\begin{tabular}{|c|c|c|c|c|c|}
\hline & $\begin{array}{c}\text { Visits } \\
n\end{array}$ & $\begin{array}{c}\text { Effective } \\
\text { visits \% }\end{array}$ & $\begin{array}{c}\text { Fruits } \\
n\end{array}$ & $\begin{array}{c}\% \\
\text { fruit set }\end{array}$ & $\begin{array}{c}\text { Seeds/fruit } \\
\overline{\mathrm{x}} \pm \mathrm{SE}\end{array}$ \\
\hline & \multicolumn{5}{|c|}{ Osmia cornuta } \\
\hline & 52 & 100 & 15 & 28.8 & $8.20 \pm 0.33$ \\
\hline & \multicolumn{5}{|c|}{ Apis mellifera } \\
\hline Nectar foragers & 70 & 31.4 & 9 & 12.9 & $7.33 \pm 0.50$ \\
\hline Pollen-nectar foragers & 106 & 99.1 & 31 & 29.3 & $7.94 \pm 0.25$ \\
\hline
\end{tabular}

Tab. III). Rate of stigma contact on the previously-bagged flowers used in this experiment (Tab. III) was similar to that of open-pollinated flowers (Tab. I) for O. cornuta. Instead, stigma contact was higher in previously-bagged flowers than in open-pollinated flowers for A. mellifera, especially for pollen-foragers (Tabs. I and III).

Although some O. cornuta were recorded as far as 120 trees $(120 \mathrm{~m})$ from the nesting shelters, most $(78.7 \%)$ foraged within the first 40 trees $(48 \mathrm{~m})$ nearest the nesting shelters. In contrast, A. mellifera (47.5\% recorded within the first 40 trees) and other pollinators (45.8\% recorded within the first 40 trees) were more evenly distributed throughout the orchard (Fig. 3). Mean fruitlet-set in the 32 trees sampled was $23.6 \pm 2.3 \%$, fruit-set at harvest $4.6 \pm$ $0.3 \%$, and seed-set $2.9 \pm 0.1$ seeds per fruit. The only independent variable included in the Stepwise Multiple Regression model for fruitlet-set $\left(\mathrm{r}^{2}=0.405 ; F=20.39 ; \mathrm{df}=1,30 ; P<0.0001\right)$ was number of flowers per tree $(\beta=-0.636 ; P<$ 0.0001 ). Thus, small trees (with fewer flowers) tended to have greater fruitlet-set, irrespective of visitation by different pollinator types. The model for seed-set $\left(\mathrm{r}^{2}=0.362 ; F=8.22 ; \mathrm{df}=\right.$ 2,$29 ; P<0.005$ ) included $O$. cornuta frequency $(\beta=0.47 ; P<0.005)$ and $A$. mellifera frequency $(\beta=0.35 ; P<0.05)$.

\subsection{Osmia cornuta population dynamics}

Osmia cornuta female emergence was high (94.2\%) for the Girona population, but low (21.6\%) for the Murcia population. Overall, 629 females emerged, of which $282(44.8 \%)$ were recorded in the night counts made one week after release. By the end of the flowering period, these females had produced 496 nests, of which 24 were incomplete (unplugged). The total number of cells produced was 2138 , of which 675 contained female and 1463 male progeny $($ sex ratio $=2.17 \AA / \%)$. Therefore, an average of 2.39 female cells, and 5.19 male cells were produced per nesting female. Mortality was similar for progeny of either sex (14.3\% of the cells produced). Most mortality occurred in the early-immature (egg, first and second larval instars) and prepupal stages (7.4\% and $4.7 \%$, respectively). Parasitism, was rare $(0.28 \%)$, and due to a single cleptoparasitic species, the drosophilid fly Cacoxenus indagator Loew.

\section{DISCUSSION}

As with other rosaceous fruit trees, A. mellifera pollen-foragers were much more effective pollinators of "Comice" pear than nectar-foragers 


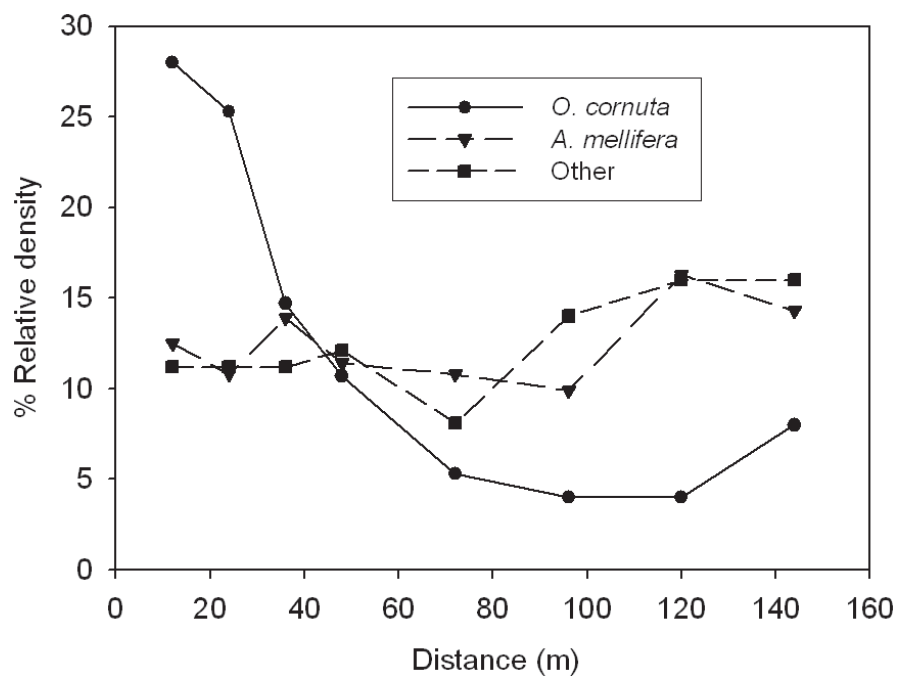

Figure 3. Distribution of Osmia cornuta, Apis mellifera and other flower-visiting insects throughout the study orchard. Y-axis: percent density of each insect group. X-axis: distance from O. cornuta nesting shelters.

(Robinson, 1979; Bosch and Blas, 1994; Vicens and Bosch, 2000a). Stigma contact in previously unvisited flowers was similar to that in open-pollinated flowers for O. cornuta. In contrast, A. mellifera were much more likely to contact the stigmas on previously unvisited flowers than on open-pollinated flowers. This result shows that single-visit experiments may sometimes overestimate pollinating effectiveness. Because they have not been visited, virgin bagged flowers are expected to have more pollen and nectar than the average open-pollinated flower. For Diervilla lonicera, accumulation of nectar in virgin bagged flowers resulted in prolonged flower-handling times and increased pollen deposition on the stigma (Thomson and Plowright, 1980). In addition, previously bagged flowers may experience a different microclimate compared to unbagged flowers, which may influence pollen and nectar presentation (Kearns and Inouye, 1993). The fact that seed-set in previously bagged flowers was high (7-8 seeds) and similar for all three pollinator types indicates that both $O$. cornuta and A. mellifera carried sufficient amounts of viable, compatible pollen for adequate fertilization, as long as stigma contact occurred. It also suggests that seed-set in these flowers may have been limited by physiological constraints or nutritional resources, rather than pollen deposition. Similar results have been obtained on almond and apple (Bosch and Blas 1994; Vicens and Bosch, 2000a). Taken together, these results question the usefulness of pollen dispensers placed at the hive entrance for orchard pollination with $A$. mellifera, and emphasizes the need to increase the proportion of pollen-foragers (with higher stigma contact rates).

Commercial size in "Comice" pears is achieved in fruits with 2-3 seeds (Joumien, 1968; Callan and Lombard, 1978). Mean seedset was 2.9 in fruits produced throughout the orchard from flowers exposed to open pollination, in contrast to 7-8 in fruits produced in the single-visit experiment. This difference suggests again that pollinator effectiveness may be overestimated in single-visit experiments due to longer visitation times in previously unvisited flowers, which would result in greater pollen deposition (Thomson and Plowright, 1980). In addition, some open-pollinated flowers could have been visited only by dipterans or other less effective pollinators. The difference in seed-set between open-pollinated fruits and single-visit fruits was not due to parthenocarpy in openpollinated flowers, since we found no fruits with 0 seeds. 
Osmia cornuta emergence was quick and well timed with pear bloom. Female $O$. cornuta established in the nesting materials provided, and, in agreement with results of Maccagnani et al. (2003), almost exclusively visited pear flowers. Just as with almond and apple (Bosch and Blas, 1994; Vicens and Bosch, 2000a), stigma contact rate and pollinating effectiveness of $O$. cornuta females on pear were very high. Despite the small size of the population released, the contribution of $O$. cornuta to "Comice" pollination in the study orchard was notable. Multiple Regression analysis showed that a significant fraction of seed-set variation in "Comice" could be explained by the distribution of $O$. cornuta in the orchard, even when honey bees were seven times more abundant. From a commercial stand point, seed-set is an important parameter, since it is positively correlated with fruit size and regular shape (Joumien, 1968; Callan and Lombard, 1978). Together with the study of Maccagani et al. (2003), our results strongly indicate that $O$. cornuta should be considered a valid alternative pollinator of pears. Despite their abundance, syrphid flies contributed little to overall pollination.

Osmia cornuta stocking rates for adequate apple pollination have been estimated at 355530 nesting females per ha (Vicens and Bosch, 2000a). This estimate was obtained assuming an average flower production of $\sim 2000$ flowers per tree and an average tree density of $\sim 2000$ trees per ha. In our "Comice" orchard, flower production was $1965 \pm 104$ flowers per tree and tree density was 2222 trees per ha. Osmia cornuta rate of stigma contact, flower visiting rate, fruit-set after one visit, and visitation fidelity (based on the pollen composition found in the provisions) on "Comice" were similar to values obtained on apple (Vicens and Bosch, 2000a). Thus, recommended stocking rates for pear pollination with $O$. cornuta would not be very different from those estimated for apple. However, because pears bloom ahead of apples (with greater risk of unfavorable weather) and because blooming periods tend to be shorter for pear than apple, slightly higher numbers of nesting females may actually be required for pear pollination. Recommended stocking rates for A. mellifera on pear are 2.5-4 colonies per ha (McGregor, 1976; Free, 1993; Benedek, 1996). Recent studies have discussed the possibility that a diverse pollinator assemblage contributes to overall pollination in more ways than just by increasing pollinator abundance (Klein et al., 2003). Different pollinator species might complement each other in terms of spatial or temporal distribution. Or the foraging behavior of a pollinator may influence the pollinating effectiveness of another pollinator. For example, yields in clover fields were sometimes higher when nectar-robbing bumblebees were present (Heinrich, 1979). Presumably, lower nectar levels in fields with nectar robbers caused legitimate pollinators to move between plants more often, thus enhancing cross-pollination. We did not observe any specific interactions between $O$. cornuta and A. mellifera. Both species can be used, together or separately, to improve pear pollination. However, if used in conjunction, stocking rates will likely have to be adjusted. Overpollination will not result in higher yields, and floral resources may be lowered to levels that hinder Osmia larval development (Torchio, 1985) or enhance dispersal of pre-nesting females (Bosch and Kemp, 2002).

The female $O$. cornuta population recovered at the end of the study (578 females) was $18.2 \%$ lower than the female population initially released, and $8.1 \%$ lower than the emerged female population. Several factors contributed to this population decrease. First, emergence of the Murcia population was very low (22\%). Inspection of the cocoons with unemerged individuals showed that most mortality occurred in the adult stage, and some cocoons were partially chewed, indicating that bees were alive when released, but not vigorous enough to come out of the cocoon. Similar observations were made in $O$. cornuta populations wintered too late in the autumn (that is, pre-wintered for too long) (Bosch, 1994a, 1995). In both O. cornuta and the closely-related Osmia lignaria Say, long pre-wintering regimes have been associated with body weight losses, fat body depletion, decreased vigor and increased winter mortality (Bosch et al., 2000; Bosch and Kemp, 2004). Given appropriate pre-wintering and wintering regimes, survival should approach $95 \%$, as with the Girona population of this study and other managed populations (Bosch, 1994a). A second factor that limited O. cornuta population growth is the poor female establishment. Only $44.8 \%$ of the emerged females actually nested in the shelters provided. Female 
dispersal is typical of populations released as single cocoons (Bosch, 1994c; Vicens and Bosch, 2000a). Better establishment $(\geq 70 \%)$ can be obtained when populations are released from natal nests (Maeta, 1978; Torchio, 1984, 1985; Bosch, 1994c), and nesting shelters are distributed evenly across the orchard, rather than grouped in a small area (Torchio, 1984; Bosch, 1994a). Pears have a short blooming period compared to other fruit trees. More studies will be needed to establish whether $O$. cornuta populations can be routinely increased in pear orchards, and if planting additional pollennectar sources within the orchard could help increase cell production by increasing the length of the nesting period (Bosch and Kemp, 2002).

\section{ACKNOWLEDGEMENTS}

We are grateful to P. Vilardell and J. Bonany (IRTA, Mas Badia, La Tallada) for their support and advice throughout the study, and to N. Vicens, M. Sala and J. Batchillí for invaluable assistance. M. Suárez-Cervera (Universitat de Barcelona) kindly determined the pollen samples, and A. Lacasa (CIDA, Murcia) provided some O. cornuta nests. We also thank M. Blas and A. Serra (Universitat de Barcelona) for providing laboratory space and access to nesting materials. The manuscript was improved through comments from J.H. Cane (USDA/ARS, Logan, Utah), B.E. Vaissière (INRA, Avignon) and two anonymous reviewers. This study was supported by a fellowship from the Instituto de Cooperación Iberoamericana to V.H. Monzón.

Résumé - Comportement de butinage et efficacité pollinisatrice d'Osmia cornuta (Hymenoptera : Megachilidae) et d'Apis mellifera (Hymenoptera : Apidae) sur la poire «Comice». La poire "Comice" est un cultivar considéré comme difficile à polliniser en raison de son auto-incompatibilité et de la brièveté de la période de pollinisation. Nous avons suivi dans un verger (Fig. 1) les butineuses d'Osmia cornuta (cat. 1), les butineuses de pollen et de nectar (cat. 2) et les butineuses de nectar seulement (cat. 3) d'Apis mellifera et enregistré les taux de contact avec le stigmate, les taux de visite (nombre de fleurs visitées par min), le nombre de fleurs visitées par arbre et les distances de vol entre les arbres. Les femelles d'O. cornuta ont émergé rapidement (Fig. 2). Elles ont visité plus de fleurs par min $(13,8)$ qu'A. mellifera $(7,1$ à 9,8$)$, mais les deux espèces ont visité le même nombre de fleurs par arbre $(6,7$ à 7,9$)$ et les fréquences de vols inter-rangs ont été semblables $(4,0$ à $7,9 \%)$ (Tabs. I et II). Le contact avec le stigmate a eu lieu dans $98,7 \%$ des cas pour les butineu- ses de catégorie 1 (O. cornuta), dans $51,8 \%$ des cas pour la catégorie 2 et dans $19,0 \%$ pour la catégorie 3 (Tab. I). Nous avons recouvert les boutons floraux de sacs en nylon puis ôté ces sacs pour permettre aux fleurs vierges d'être visitées une fois soit par $O$. cornuta, soit par A. mellifera. La mise à fruits de ces fleurs visitées une seule fois a été de $28,8 \%$ pour les butineuses de catégorie 1 , de $29,3 \%$ pour la catégorie 2 et de $12,9 \%$ pour la catégorie 3 (Tab. III). Le contact avec le stigmate était plus élevé pour $A$. mellifera chez les fleurs qui avaient été ensachées, alors qu'O. cornuta se comportait de la même façon sur les deux types de fleurs (Tabs. I et II). La nouaison chez les fleurs visitées une seule fois et qui ont donné des fruits a été semblable pour les trois catégories de butineuses $(7,3$ à 8,2$)$ (Tab. III). La plupart des femelles d'O. cornuta $(78,7 \%)$ ont butiné dans un rayon de $48 \mathrm{~m}$ autour de leur site de nidification (Fig. 3). Les nids d'O. cornuta ont été approvisionnés à $94,4 \%$ en pollen de poirier. L'analyse de régression multiple pas à pas a montré que la mise à fruits dans le verger était principalement liée à la taille des arbres (les arbres avec moins de fleurs avaient une plus grande mise à fruits) $(\beta=-0,64$; $P<0,001$ ), alors que la nouaison s'expliquait mieux par la répartition d' $O$. cornuta $(\beta=0,47 ; P<0,005)$ et d'A. mellifera $(\beta=0,35 ; P<0,05)$. On peut donc détecter la contribution d' $O$. cornuta à la pollinisation bien que les butineuses d' A. mellifera soient sept fois plus abondantes. La mortalité hivernale a été basse chez l'une des populations d' $O$. cornuta $(5,8 \%)$ mais plus forte chez l'autre $(78,4 \%)$. Dans l'ensemble les femelles se sont installées lentement (44,8\% des femelles ayant émergé). Le résultat est que la population de femelles d' $O$. cornuta retrouvée à la fin de l'étude a été de 18,2\% inférieure à la population lâchée. La discussion porte sur une gestion pré-hivernale correcte afin de réduire la mortalité hivernale et sur des méthodes pour accroître l'installation des populations d'O. cornuta.

Osmia cornuta / Apis mellifera / efficacité pollinisatrice / pollinisation / poirier

Zusammenfassung - Sammelverhalten und Bestäubungseffizienz von Osmia cornuta (Hymenoptera: Megachilidae) und Apis mellifera (Hymenoptera: Apidae) an „Comice“ Birnen. Wir untersuchten das Sammelverhalten und die Bestäubungseffizienz von Osmia cornuta (Latreille) und Apis mellifera L. in einer "Comice" Birnenplantage (Abb. 1). Dieses Kultivat wird wegen seiner Selbstinkompatibilität und den kurzen effektiven Bestäubungzeiten als schwierig zu bestäuben angesehen. Wir folgten Sammlerinnen in der Birnenplantage und registrierten die Stigmakontaktraten, die Blütenbesuchsraten (Anzahl besuchter Blüten pro Minute), die Anzahl von aufeinanderfolgend besuchten Blüten pro Baum und die Flugstrecken zwischen besuchten Bäumen. Die Weibchen von Osmia cornuta schlüpften sofort (Abb. 2). Sie 
besuchten mehr Blüten pro Minute $(13,8)$ als A. mellifera $(7,1-9,8)$, aber beide Bestäuberarten besuchten ähnliche Anzahlen von Blüten pro Baum (6,7$7,9)$ und zeigten ähnliche Flugfrequenzen zwischen den Reihen, (4,0-7,9\%) (Tab. I und II). Der Stigmenkontakt war $98,7 \%$ bei $O$. cornuta, $51,8 \%$ bei A. mellifera Pollen-Nektarsammlerinnen und $19,0 \%$ bei A. mellifera Nektarsammlerinnen (Tab. III). Wir bedeckten Blütenstände mit Nylonsäckchen und entfernten diese dann, um jungfräuliche Blüten einem einmaligen Besuch von O. cornuta oder von A. mellifera auszusetzen. Der Fruchtansatz an diesen einmal besuchten Blüten war $28,8 \%$ bei $O$. cornuta, $29,3 \%$ bei A. mellifera Pollen-Nektarsammlerinnen und $12,9 \%$ bei $A$. mellifera Nektarsammlerinnen (Tab. III). Der Stigmenkontakt von A. mellifera war bei den zuvor eingesackten Blüten höher als bei offenbestäubten Blüten, während $O$. cornuta sich auf beiden Blütentypen ähnlich verhielt (Tab. I und III). Der Fruchtansatz bei einmal besuchten Blüten, der sich danach zu Früchten weiterentwickelte war bei allen drei Bestäubertypen ähnlich $(7,3-8,2)$ (Tab. III). Die meisten (78,7\%) O. cornuta Weibchen sammelten innerhalb von $48 \mathrm{~m}$ Entfernung von ihrem Nest (Abb. 3). Osmia cornuta Nester wurden zu 94,4\% mit Birnenpollen versorgt. Eine schrittweise multiple Regressionsanalyse zeigte, dass der Fruchtansatz über die Plantage am meisten mit der Baumgröße zusammenhing (Bäume mit weniger Blüten hatte einen höheren Fruchtansatz ( $\beta=-0,64$; $P<0,001)$, während der Samenansatz am besten durch die Verteilung von $O$. cornuta $(\beta=0,47 ; P<$ $0,005)$ und $A$. mellifera $(\beta=0,35 ; P<0,05)$ erklärt wurde. Daher konnte der Bestäuberbeitrag von $O$. cornuta noch erkannt werden, obwohl A. mellifera siebenfach häufiger vertreten war. Die Wintersterblichkeit war in einer der eingesetzten $O$. cornuta Populationen niedrig $(5,8 \%)$, in der anderen aber hoch $(78,4 \%)$. Die Gesamterzeugung an Weibchen war niedrig (44,8\% der geschlüpften Weibchen). Als Resultat war die am Ende der Untersuchung wiedergefundene Population von weiblichen $O$. cornuta um 18,2\% kleiner als die ausgesetzte Population. Wir diskutieren daher angemessenes Vorwintermanagement, um die Wintermortalität zu verringern und Methoden, um die Etablierung einer Population $\mathrm{zu}$ verbessern.

Osmia cornuta / Apis mellifera / Bestäubungseffizienz / Birnenbestäubung

\section{REFERENCES}

Asensio E. (1984) Osmia (Osmia) cornuta Latr pollinisateur potentiel des arbres fruitiers en Espagne (Hymenoptera, Megachilidae), in: Proc. V Symp. Int. Pollinisation, 27-30 September 1983, Versailles, pp. 461-465.

Beattie A.J. (1971) A Technique for the study of insectborne pollen, Pan. Pac. Entomol. 47, 82.
Benedek P. (1996) Insect pollination of fruit crops, in: Nyéki J., Soltész M. (Eds.), Floral biology of temperate zone fruit trees and small fruits, Akadémiai Kiadó, Budapest, pp. 287-340.

Bini G., Bellini E. (1971) Macrosporongenesi nella cultivar di pero "Decana di Comizio" e ricerca dil periodo più opportuno per la sua impollinazione, Riv. Ortiflorofrut. Ital. 4, 322-337.

Bosch J. (1994a) Improvement of field management of Osmia cornuta (Latreille) (Hymenoptera, Megachilidae), Apidologie 25, 71-83.

Bosch J. (1994b) The nesting behaviour of the mason bee Osmia cornuta (Latr) with special reference to its pollinating potential (Hymenoptera, Megachilidae), Apidologie 25, 84-93.

Bosch J. (1994c) Osmia cornuta Latr. (Hym., Megachilidae) as a potential pollinator in almond orchards, Releasing methods and nest-hole length, J. Appl. Entomol. 117, 151-157.

Bosch J. (1995) Comparison of nesting materials for the orchard pollinator Osmia cornuta (Hymenoptera: Megachilidae), Entomol. Gen. 19, 285-289.

Bosch J., Blas M. (1994) Foraging behaviour and pollinating efficiency of Osmia cornuta and Apis mellifera on almond (Hymenoptera: Megachilidae, Apidae), Appl. Entomol. Zool. 29, 1-9.

Bosch J., Kemp W.P. (2002) Developing and establishing bee species as crop pollinators: the example of Osmia spp. (Hymenoptera: Megachilidae) and fruit trees, Bull. Entomol. Res. 92, 3-16.

Bosch J., Kemp W.P. (2004) Effect of pre-wintering and wintering temperature regimes on weight loss, survival, and emergence time in the mason bee Osmia cornuta (Hymenoptera: Megachilidae), Apidologie 35, 469-479.

Bosch J., Kemp W.P., Peterson S.S. (2000) Management of Osmia lignaria (Hymenoptera: Megachilidae) populations for almond pollination: Methods to advance bee emergence, Environ. Entomol. 29, 874-883.

Callan N., Lombard P. (1978) Pollination effects on fruit and seed development in "Comice" pear, J. Am. Soc. Hortic. Sci. 103, 496-500.

Crisosto C., Lombard P., Sugar D., Polito V. (1988) Putrescine influences ovule senescence, fertilization time, and fruit set in "Comice" pear, J. Am. Soc. Hortic. Sci. 113, 708-712.

Free J.B. (1993) Insect pollination of crops, Academic Press, London.

Heinrich B. (1979) Bumblebee economics, Harvard University Press, Cambridge.

Joumien F. (1968) The causes of poor bearing of pear trees of variety "Doyenne du Comice", Acta Agrobot. $21,75-106$.

Klein A.-M., Steffan-Dewenter I., Tscharntke T. (2003) Fruit set of highland coffee increases with 
the diversity of pollinating bees, Proc. R. Soc. London B 270, 955-961.

Kearns C.A., Inouye D.W. (1993) Techniques for pollination biologists, University Press of Colorado, Niwot.

Krunic M.D., Brajkovic M.M., Mihajlovic L.S. (1991) Management and utilization of Osmia cornuta Latr. for orchard pollination in Yugoslavia, Acta Hortic. 288, 190-193.

Lombard P., Cordy C., Hansen E. (1971) Relation of postbloom temperatures to "Bartlett" pear maturation, J. Am. Soc. Hortic. Sci. 96, 799-801.

Maeta Y. (1978) Comparative studies on the biology of the bees of the genus Osmia of Japan, with special reference to their management for pollination of crops (Hymenoptera: Megachilidae), Tohoku Natl. Agric. Exp. Stn. Bull. 57, 1-221 [in Japanese].

Maccagnani B., Ladurner E., Santi F, Burgio G. (2003) Osmia cornuta (Latreille) (Hymenoptera: Megachlidae) as a pollinator of pear (Pyrus communis L.): fruit- and seed-set, Apidologie 34, 207-216.

Márquez J., Bosch J., Vicens N. (1994) Pollens collected by wild and managed populations of the potential orchard pollinator Osmia cornuta Latreille, J. Appl. Entomol. 117, 353-359.

McGregor S.E. (1976) Insect pollination of cultivated plants, Agricultural Handbook No. 496, ARSUSDA, Washington DC.

Nyéki J. (1996) Fertilization conditions, in: Nyéki J., Soltész M. (Eds.), Floral biology of temperate zone fruit trees and small fruits, Akadémiai Kiadó, Budapest, pp. 185-256.

Nyéki J., Bubán T. (1996) Pollination and fertilization, in: Nyéki J., Soltész M. (Eds.), Floral biology of temperate zone fruit trees and small fruits, Akadémiai Kiadó, Budapest, pp. 153-184.

Quinn G.P., Keough M.J. (2002) Experimental design and data analysis for biologists, Cambridge University Press, Cambridge.

Robinson W.S. (1979) Effect of apple cultivar on foraging behaviour and pollen transfer by honey bees, J. Am. Soc. Hortic. Sci. 104, 596-598.
Sokal R.R., Rohlf F.J. (1995) Biometry, W.H. Freeman and Company, New York.

Soltész M. (1996a) Requirements for successful fruit set in orchards, in: Nyéki J., Soltész M. (Eds.), Floral biology of temperate zone fruit trees and small fruits, Akadémiai Kiadó, Budapest, pp. 257-286.

Soltész M. (1996b) Flowering, in: Nyéki J., Soltész M (Eds.), Floral biology of temperate zone fruit trees and small fruits, Akadémiai Kiadó, Budapest, pp. 80-131.

Sotes Ruiz V. (1977) Study on the pollination and fruitset on "Blanca de Aranjuez" pear, Acta Hortic. 69, 235-241.

Stephen W.P. (1958) Pear pollination studies in Oregon, Bull. Oreg. Agric. Exp. Stn. 43.

Thomson J.D., Plowright R.C. (1980) Pollen carryover, nectar rewards, and pollinator behavior with special reference to Diervilla lonicera, Oecologia $46,68-74$.

Torchio P.F. (1984) Field experiments with the pollinator species, Osmia lignaria propinqua Cresson (Hymenoptera: Megachilidae) in apple orchards: III, 1977 studies, J. Kans. Entomol. Soc. 57, $517-$ 521.

Torchio P.F. (1985) Field experiments with the pollinator species, Osmia lignaria propinqua Cresson in apple orchards: V, (1979-1980), methods of introducing bees, nesting success, seed counts, fruit yields (Hymenoptera: Megachilidae), J. Kans. Entomol. Soc. 58, 448-464.

Torchio P.F., Asensio E. (1985) The introduction of the European bee, Osmia cornuta Latr., into the U.S. as a potential pollinator of orchard crops, and a comparison of its manageability with Osmia lignaria propinqua Cresson (Hymenoptera: Megachilidae), J. Kans. Entomol. Soc. 58, 42-52.

Vicens N., Bosch J. (2000a) Pollinating efficacy of Osmia cornuta and Apis mellifera (Hymenoptera: Megachilidae, Apidae) on "Red Delicious" apple, Environ. Entomol. 29, 235-240.

Vicens N., Bosch J. (2000b) Nest site orientation and relocation of populations of the orchard pollinator Osmia cornuta (Hymenoptera: Megachilidae), Environ. Entomol. 29, 69-75. 